\title{
MYB transcription factor isolated from Raphanus sativus enhances anthocyanin accumulation in chrysanthemum cultivars
}

\author{
Eun Sun Kee ${ }^{1}$ Aung Htay Naing ${ }^{1}$ Sun Hyung $\operatorname{Lim}^{2} \cdot$ Jeung Sul Han ${ }^{1}$ \\ Chang Kil Kim ${ }^{1}$
}

Received: 1 September 2015/Accepted: 12 November 2015/Published online: 23 February 2016

(C) The Author(s) 2016. This article is published with open access at Springerlink.com

\begin{abstract}
A MYB transcription factor gene, RsMYBl, from radish was introduced into the chrysanthemum cultivars 'Peach ND', 'Peach Red', and 'Vivid Scarlet' under the control of the cauliflower mosaic virus $35 \mathrm{~S}$ promoter. Presence of $R s M Y B 1$ in transgenic lines was confirmed using polymerase chain reaction (PCR). Results of reverse-transcription-PCR analysis revealed that the expression of $R S M Y B 1$ was stable in all transgenic lines and could enhance the expression levels of three key biosynthetic genes $(F 3 H, D F R$, and $A N S)$ involved in anthocyanin production. Accordingly, anthocyanin content was significantly higher in transgenic lines than in control of all the cultivars, although the increasement was not visually observed in any of the transgenic lines. Therefore, these results demonstrate that RSMYBI has potential to enhance anthocyanin content in the chrysanthemums.
\end{abstract}

Keywords Anthocyanin - RT-PCR - Spectrophotometer · Transcription factor

\section{Introduction}

Chrysanthemum morifolium Ramat. is one of the most important floricultural crops that occupies a prominent position in flower markets worldwide. In 2012, its cultivation

Chang Kil Kim

ckkim@knu.ac.kr

Aung Htay Naing

aunghtaynaing2005@gmail.com

1 Department of Horticultural Science, Kyungpook National University, Daegu 702-701, Korea

2 National Academy of Agricultural Science, Rural Development Administration, Suwon 441-707, Korea area was $31 \%$ of the total cut-flower cultivation area (1724 ha) in Korea (Ministry of Agriculture, Food, and Rural Affairs, 2012), and it has been increasing on a yearly basis. In summer, the heat stress due to elevated temperatures causes degradation of anthocyanin accumulation in flower petals, leading to low flower quality that causes economic loss in chrysanthemum fields (Eun et al. 2008).

Temperature has been considered as an important factor that influences anthocyanin biosynthesis in various plants, such as apple (Ubi et al. 2006; Lin-Wang et al. 2011), grape (Yamane et al. 2006), petunia (Shvarts et al. 1997), red orange (Lo Piero et al. 2005), and rose (Dela et al. 2003). Elevated temperatures decrease the accumulation of anthocyanin. Huh et al. (2008) claimed that flower coloration was observed in red chrysanthemum cultivars when they were grown at an elevated temperature $\left(35^{\circ} \mathrm{C}\right)$.

Genetic engineering with MYB transcription factors has been used to enhance anthocyanin accumulation in several plant species, since MYB transcription factors up-regulated anthocyanin biosynthesis in tobacco, petunia, apple, rose, and lily (Espley et al. 2007; Lin-Wang et al. 2010; Pattanaik et al. 2010; Quattrocchio et al. 2006; Yamagishi et al. 2010). Pattanaik et al. (2010) reported that overexpression of MYB (NtAn2) in tobacco enhanced anthocyanin accumulation and expression levels of chalcone synthase $(\mathrm{CHS})$, chalcone isomerase $(\mathrm{CHI})$, flavanone 3-hydroxylase $(F 3 H)$, dihydroflavonol 4-reductase $(D F R)$, and anthocyanidin synthase $(A N S)$ genes. In apples, red fruit color is controlled by MdMYB10 (Espley et al. 2007). The purple phenotype of sweet potato is also strongly associated with IbMYB1, which induces all anthocyanin biosynthetic genes (Mano et al. 2007). LhMYB6 and LhMYB12 increase the expression levels of anthocyanin biosynthetic genes and determine the accumulation of anthocyanin (Yamagishi et al. 2010). Radish MYB 
transcription factor belongs to the R2R3-MYB transcription factor family and is highly expressed in the skin and flesh of three radish cultivars ('Seo Ho', 'Man Tang Hong', and 'Hong Feng No.1'); strong anthocyanin accumulation has been observed in the radish cultivars (Park et al. 2011). Expression of the MYB transcription factor in petunia enhanced the expression level of anthocyanin biosynthetic genes ( $C H I, C H S, F 3 H, D F R$, and $A N S$ ) as well as anthocyanin accumulation in our previous studies. Since the main anthocyanin biosynthesis pathway in chrysanthemum is the cyanidin-based pathway, $C H S, C H I, F 3 H, D F R$, and $A N S$ are considered as the five key biosynthetic genes responsible for anthocyanin accumulation in chrysanthemums. Thus, it is quite interesting to investigate the role of RsMYBI in anthocyanin accumulation in chrysanthemum.

In this study, we used three different red chrysanthemum cultivars that have been observed to show coloration in summer. RsMYBI was introduced into the cultivars by using Agrobacterium-mediated transformation. Expression levels of anthocyanin biosynthetic genes regulated by $R s M Y B$ and associated anthocyanin accumulation were analyzed.

\section{Materials and methods}

Three red chrysanthemum cultivars (C. morifolium Ramat.), namely, 'Peach ND', 'Peach Red', and 'Vivid scarlet', were obtained from Gumi Research Station. The cultivars were then proliferated in vitro, according to the method described by Naing et al. (2015a). Briefly, shoot tips with about $1 \mathrm{~cm}^{2}$ in size were cultured on Murashige and Skoog medium (MS; Duchefa Biochemie, Netherlands) containing $3 \%(\mathrm{w} / \mathrm{v})$ sucrose, $0.8 \%$ plant agar, and $0.01 \%$ activated charcoal. Then, the cultures were maintained at $25 \pm 2{ }^{\circ} \mathrm{C}$ and a 16-h photoperiod (37 $\mu \mathrm{mol} \mathrm{m} \mathrm{m}^{-2} \mathrm{~s}^{-1}$ )

\section{Plasmid construction and transformation}

In this study, Agrobacterium tumefaciens strain C58C1 carrying a binary vector $\mathrm{pB} 7 \mathrm{WG} 2 \mathrm{D}$ with $R s M Y B 1$ isolated from radish (Raphanus sativus L.) was used. RsMYB1 was placed under the control of the cauliflower mosaic virus $35 \mathrm{~S}$ promoter. In addition, the vector contained the gene bar for resistance to phosphinothricin (PPT) in transgenic plants.

Prior to transformation, infection solution of Agrobacterium strain harboring the binary vector $\mathrm{pB} 7 \mathrm{WG} 2 \mathrm{D}$ were cultured as described by Naing et al. (2014), and transformation was performed according to protocol described by Naing et al. (2016). Briefly, 100 leaf segments $\left(5 \mathrm{~cm}^{2}\right)$ excised from in vitro plants of the three different cultivars were incubated in the Agrobacterium infection solution.
The leaf segments were cultured on an MS co-cultivation medium with $0.5 \mathrm{mg} \mathrm{L}^{-1}$ of BA and $0.5 \mathrm{mg} \mathrm{L}^{-1}$ of NAA, $3 \%$ sucrose, and $3 \mathrm{~g} \mathrm{~L}^{-1}$ of Gelrite $(\mathrm{pH} 5.8)$ and placed in the dark at $25 \pm 2{ }^{\circ} \mathrm{C}$ for 3 days. Then, the leaf segments were cultured on the same medium containing $125 \mathrm{mg} \mathrm{L}^{-1}$ Clavamox (Zoetis, India) and placed in the dark at $25 \pm 2{ }^{\circ} \mathrm{C}$ for 7 days. The leaf segments were further cultured on the same medium containing $1 \mathrm{mg} \mathrm{L}^{-1}$ of PPT and $125 \mathrm{mg} \mathrm{L}^{-1}$ of Clavamox under a 16-h photoperiod $\left(37 \mu \mathrm{mol} \mathrm{m}{ }^{-2} \mathrm{~s}^{-1}\right)$. They were transferred to a fresh medium every 3 weeks to suppress Agrobacterium growth. After 6 weeks, green shoots resistant to PPT were collected and transferred to plant growth regulator-free MS medium with $1 \mathrm{mg} \mathrm{L}^{-1} \mathrm{PPT}$ and $125 \mathrm{mg} \mathrm{L}^{-1}$ of Clavamox to assess plant growth. PPT-resistant plants that were $4-5 \mathrm{~cm}$ in size were transplanted to a tray with vermiculite soil and acclimatized in a greenhouse at $25^{\circ} \mathrm{C}$. The plantlets were then transferred to pots filled with peat soil and placed in the greenhouse.

\section{DNA extraction and polymerase chain reaction}

Genomic DNA was extracted from young leaves of 6-week-old plants selected using $1 \mathrm{mg} \mathrm{L}^{-1}$ PPT with the RBC HiYield ${ }^{\mathrm{TM}}$ Genomic DNA Mini Kit (Real Biotech Corporation, Taiwan), according to manufacturer's instructions. Genomic DNA was then amplified using polymerase chain reaction (PCR) with specific primers and PCR conditions mentioned in Table 1 . To detect presence of RSMYBI and bar, amplified DNA was observed under UV (UVITEC Cambridge, UK) irradiation after electrophoresis for 30 min using $2 \%$ agarose gel and staining with ethidium bromide.

\section{RNA extraction and reverse transcription-PCR}

To evaluate the expression level of RsMYBI and anthocyanin biosynthetic genes in the transgenic lines already confirmed using PCR, RNA of each line was extracted for reverse transcription (RT)-PCR analysis. Prior to RNA extraction, all equipment, including reagent bottles, were cleaned using RNA eraser (MP Bio, USA). Total RNA was isolated from $100 \mathrm{mg}$ of leaf tissue of the transgenic and wild type chrysanthemum plants by using TRI Reagent ${ }^{\mathrm{TM}}$ Solution (Ambion, USA), according to the manufacturer's instructions. Complementary DNA (cDNA) was synthesized from $100 \mathrm{ng}$ of total RNA by using the High Capacity cDNA Reverse Transcription Kit (Applied Biosystems, USA), according to the manufacturer's protocol. Primers and PCR conditions for RsMYBI remained unchanged, and those for the biosynthetic genes ( $\mathrm{CHI}$, CHS, F3H, DFR, and ANS) are listed in Table 1; Actin was used as the internal control. PCR products were observed 
Table 1 Primers and PCR conditions used in this study

\begin{tabular}{|c|c|c|c|}
\hline Gene & Primer & $\begin{array}{l}\text { Size } \\
(\mathrm{bp})\end{array}$ & PCR condition \\
\hline$R s M Y B 1$ & $\begin{array}{l}\text { F-ATG GAG GGT TCG TCC AAA GG } \\
\text { R-GAA ACA CTA ATC AAA TTA CAC AGT } \\
\text { CTC TCC }\end{array}$ & 700 & $\begin{array}{l}98^{\circ} \mathrm{C} \text { for } 30 \mathrm{~s} \text {, followed by } 25 \text { cycles including } 10 \mathrm{~min} \text { at } 98^{\circ} \mathrm{C}, 1 \mathrm{~min} \\
\text { at } 98{ }^{\circ} \mathrm{C} \text { and } 1 \text { min at } 72^{\circ} \mathrm{C} \text {, and final elongation step at } 72{ }^{\circ} \mathrm{C} \text { for } \\
1 \mathrm{~min}\end{array}$ \\
\hline Bar & $\begin{array}{l}\text { F-GGT CTG CAC CAT CGT } \\
\text { R-TCA GAT TTC GGT GAC GGG CA }\end{array}$ & 496 & $\begin{array}{l}95^{\circ} \mathrm{C} \text { for } 2 \mathrm{~min} \text {, followed by } 30 \text { cycles including } 20 \mathrm{~s} \text { at } 95^{\circ} \mathrm{C}, 30 \mathrm{~s} \text { at } \\
55^{\circ} \mathrm{C} \text { and } 30 \mathrm{~s} \text { at } 72{ }^{\circ} \mathrm{C} \text {, and final elongation step at } 72{ }^{\circ} \mathrm{C} \text { for } 5 \mathrm{~min}\end{array}$ \\
\hline $\mathrm{CHS}$ & $\begin{array}{l}\text { F-CAA CGG TTT TCT CCA TTA GGT } \\
\text { R-GAG GAC CAC GGT TTC GAC }\end{array}$ & 299 & $\begin{array}{l}95^{\circ} \mathrm{C} \text { for } 2 \mathrm{~min} \text {, followed by } 30 \text { cycles including } 20 \mathrm{~s} \text { at } 95^{\circ} \mathrm{C}, 40 \mathrm{~s} \text { at } \\
57^{\circ} \mathrm{C} \text { and } 30 \mathrm{~s} \text { at } 72{ }^{\circ} \mathrm{C} \text {, and final elongation step at } 72{ }^{\circ} \mathrm{C} \text { for } 5 \mathrm{~min}\end{array}$ \\
\hline $\mathrm{CHI}$ & $\begin{array}{l}\text { F-TGG TGC AAC CAT TGA CAA GT } \\
\text { R-AAA TTT GGT TCA GCA TCT GTA GTT }\end{array}$ & 300 & $\begin{array}{l}95{ }^{\circ} \mathrm{C} \text { for } 2 \mathrm{~min} \text {, followed by } 30 \text { cycles including } 20 \mathrm{~s} \text { at } 95{ }^{\circ} \mathrm{C}, 40 \mathrm{~s} \text { at } \\
55.6^{\circ} \mathrm{C} \text { and } 30 \mathrm{~s} \text { at } 72{ }^{\circ} \mathrm{C} \text {, and final elongation step at } 72{ }^{\circ} \mathrm{C} \text { for } 5 \mathrm{~min}\end{array}$ \\
\hline$F 3 H$ & $\begin{array}{l}\text { F-ACC CGG TTC GTC CGT GAT GAG G } \\
\text { R-TGC CTG GTG GTC CGC ATT CT }\end{array}$ & 804 & $\begin{array}{l}95^{\circ} \mathrm{C} \text { for } 2 \mathrm{~min} \text {, followed by } 30 \text { cycles including } 20 \mathrm{~s} \text { at } 95^{\circ} \mathrm{C}, 40 \mathrm{~s} \text { at } \\
64{ }^{\circ} \mathrm{C} \text { and } 30 \mathrm{~s} \text { at } 72{ }^{\circ} \mathrm{C} \text {, and final elongation step at } 72^{\circ} \mathrm{C} \text { for } 5 \mathrm{~min}\end{array}$ \\
\hline$D F R$ & $\begin{array}{l}\text { F-ATG AAA GAA GAC TCA CCA GCC A } \\
\text { R-CTT CGT GAG TGT CCG CCT TT }\end{array}$ & 1048 & $\begin{array}{l}95^{\circ} \mathrm{C} \text { for } 2 \mathrm{~min} \text {, followed by } 30 \text { cycles including } 20 \mathrm{~s} \text { at } 95^{\circ} \mathrm{C}, 40 \mathrm{~s} \text { at } \\
59^{\circ} \mathrm{C} \text { and } 30 \mathrm{~s} \text { at } 72{ }^{\circ} \mathrm{C} \text {, and final elongation step at } 72{ }^{\circ} \mathrm{C} \text { for } 5 \mathrm{~min}\end{array}$ \\
\hline$A N S$ & $\begin{array}{l}\text { F-ATA CAT CCG AAC ACA AGA TG } \\
\text { R-AAT CGC TAG GTG TCG AGG GCC }\end{array}$ & 432 & $\begin{array}{l}95^{\circ} \mathrm{C} \text { for } 2 \mathrm{~min} \text {, followed by } 30 \text { cycles including } 20 \mathrm{~s} \text { at } 95^{\circ} \mathrm{C}, 40 \mathrm{~s} \text { at } \\
60^{\circ} \mathrm{C} \text { and } 30 \mathrm{~s} \text { at } 72{ }^{\circ} \mathrm{C} \text {, and final elongation step at } 72{ }^{\circ} \mathrm{C} \text { for } 5 \mathrm{~min}\end{array}$ \\
\hline Actin & $\begin{array}{l}\text { F-ACA ACG TTT TAC AAT GAG CTT CG } \\
\text { R-CCG TTC AGC AGT TGT AGT AA }\end{array}$ & 196 & $\begin{array}{l}95^{\circ} \mathrm{C} \text { for } 2 \mathrm{~min} \text {, followed by } 30 \text { cycles including } 20 \mathrm{~s} \text { at } 95^{\circ} \mathrm{C}, 40 \mathrm{~s} \text { at } \\
57^{\circ} \mathrm{C} \text { and } 30 \mathrm{~s} \text { at } 72{ }^{\circ} \mathrm{C} \text {, and final elongation step at } 72{ }^{\circ} \mathrm{C} \text { for } 5 \mathrm{~min}\end{array}$ \\
\hline
\end{tabular}

under UV (UVITEC Cambridge, UK) irradiation after electrophoresis for $30 \mathrm{~min}$ using $2 \%$ agarose gel and staining with ethidium bromide.

\section{Analysis of anthocyanin content}

Total anthocyanin contents of the transgenic lines and control plants were analyzed according to the protocol used by Naing et al. (2015b), with some modifications. Briefly, approximately $500 \mathrm{mg}$ of leaf materials excised from the plants grown in the greenhouse was crushed, and pigments were extracted with $5 \mathrm{~mL}$ of distilled water. They were then incubated overnight at $4{ }^{\circ} \mathrm{C}$ by adding $5 \mathrm{~mL}$ of $1 \%$ (w/v) hydrochloric acid in methanol solution. The supernatant was collected after centrifugation at $3000 \mathrm{rpm}$ for $20 \mathrm{~min}$ and transferred to a $2 \mathrm{~mL}$ collection tube. Absorbance was measured at $430-630 \mathrm{~nm}$ by using a spectrophotometer (U-2800; Hitachi, Tokyo, Japan). Anthocyanin content of each sample was calculated according to the method reported by Sung et al. (2013).

\section{Statistical analysis}

For measurement of anthocyanin content, five samples from each plant (wild type and two independent transgenic lines) of the three chrysanthemum cultivars were detected. Data were analyzed using Duncan Multiple Range Test (DMRT) $(p>0.05)$.

\section{Results}

\section{Generation of chrysanthemum transgenic plants that express $R s M Y B 1$}

To investigate whether RsMYBl could enhance the expression level of biosynthetic genes responsible for anthocyanin biosynthesis, we produced two independent transgenic lines from the cultivars 'Peach ND', 'Peach Red', and 'Vivid Scarlet', in which the presence of the selection marker and transgene were detected using PCR (Fig. 1). Interestingly, enhanced anthocyanin expression was not observed in the transgenic plants of the cultivars. Thus, it was necessary to investigate the expression levels of the transgene and anthocyanin biosynthetic genes.

\section{Expression analysis of $R s M Y B 1$ and anthocyanin biosynthetic genes}

We used the two independent transgenic lines derived from each cultivar to perform an expression analysis of RsMYBI and anthocyanin biosynthetic genes. Results of RT-PCR showed that distinct and stable expression of $R s M Y B 1$ in all individual lines of the same genotype (Fig. 2), but its expression level was different along with different genotype tested. Surprisingly, distinct and stable expression of RsMYB1 in the cultivars did not enhance anthocyanin production. 
Fig. 1 PCR detection of selection marker (bar), target (RsMYBl) genes in transgenic chrysanthemum (cvs. Peach ND (PN), Peach Red (PR), and Vivid Scarlet (VD) lines 1 and 2
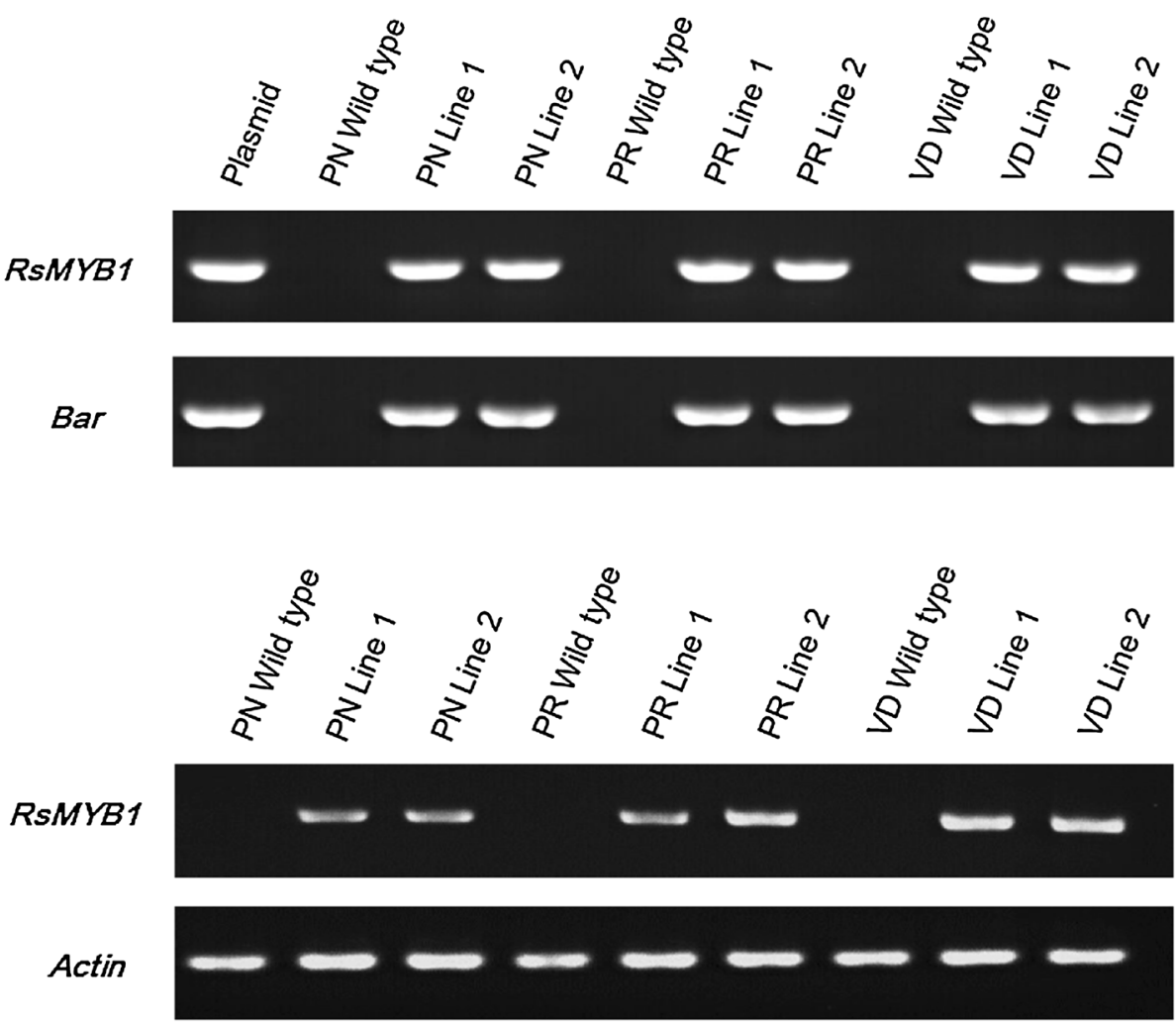

Fig. 2 RT-PCR analysis of RsMYB1 expression in the nontransgenic lines (wild type) and the transgenic lines of the chrysanthemum cultivars, namely, Peach ND (PN), Peach Red (PR), and Vivid Scarlet (VD) plants, only slight significant color difference was observed in 'Peach Red' and 'Peach ND' while a distinct variation was seen in 'Vivid Scarlet' (Fig. 4). This was further confirmed using spectrophotometry results, which were not consistent with the results for anthocyanin color in (Fig. 5) in 'Peach Red', 'Peach ND' because anthocyanin contents were observed to be significantly different in the cultivars (Fig. 5), where the contents in transgenic lines were approximately $0.01-0.015 \mathrm{mg} \mathrm{g}^{-1}$ higher than those in the controls, regardless of genotypes. Thus, higher expression levels of the three biosynthetic genes were associated with anthocyanin accumulation in the cultivars.

\section{Discussion}

Transcription factors can regulate genes involved in the anthocyanin biosynthetic pathway in various plants, including model plants and floricultural or food crops (Nishihara and Nakatsuka 2011). R2R3 MYB transcription factors, which regulate anthocyanin biosynthesis, cloned from petunia (Quattrocchio et al. 2006), apple, strawberry, plum and rose (Lin-Wang et al. 2010), lily (Yamagishi et al. 2010), snapdragon (Jackson et al. 1991), morning glory (Morita et al. 2006), gentian (Nakatsuka et al. 2008) and tobacco (Pattanaik et al. 2010) have been shown to regulate sets of genes in the anthocyanin biosynthetic genic lines and compared to the extracts from the control 
Fig. 3 RT-PCR analysis of the expression patterns of biosynthetic genes in nontransgenic lines (wild type) and two individual transgenic lines of the chrysanthemum cultivars, namely, Peach ND (PN), Peach Red (PR), and Vivid Scarlet (VD) containing RsMYB1

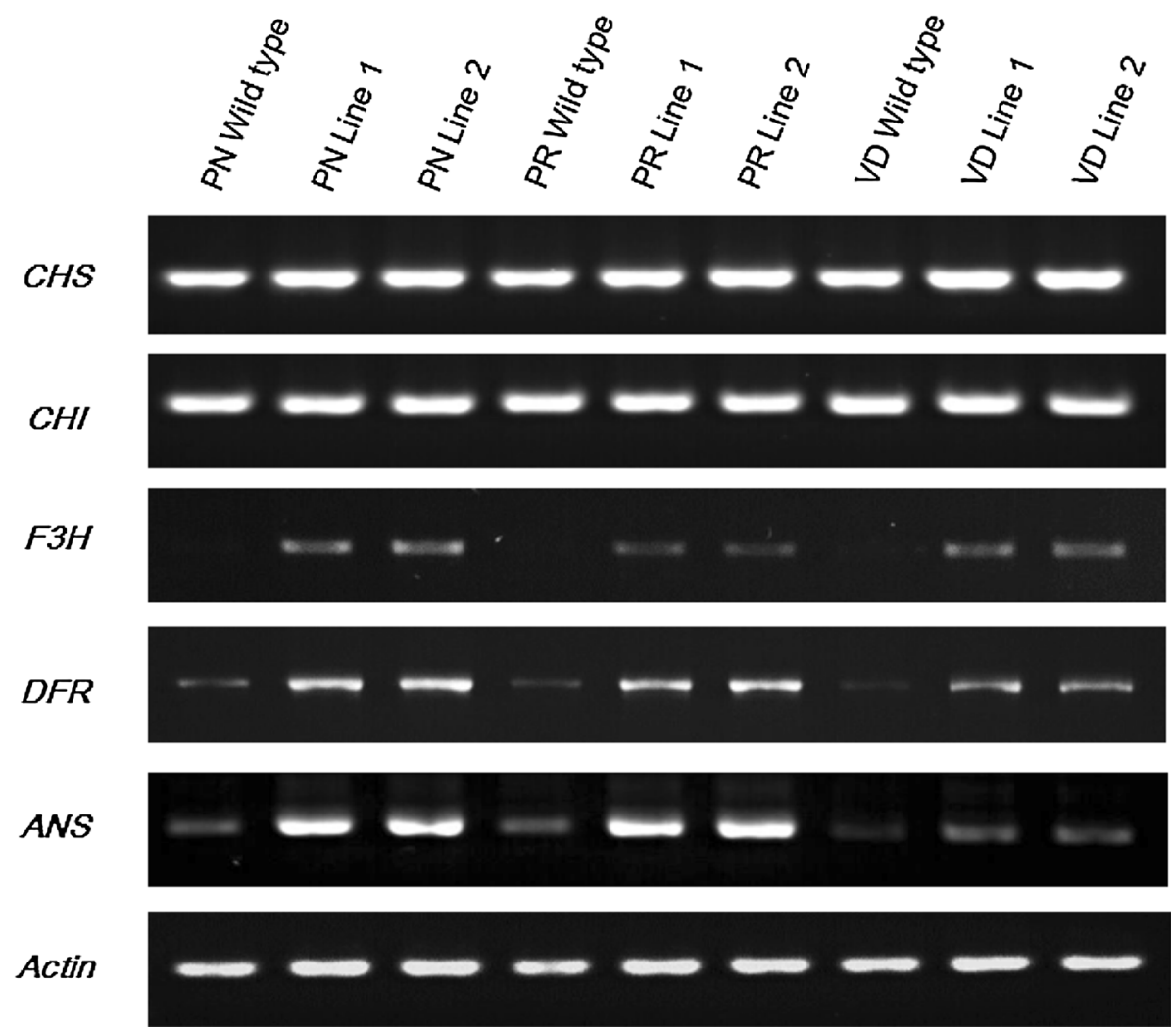

Fig. 4 Comparative analysis of anthocyanin content between the non-transgenic lines (wild type) and transgenic lines of the chrysanthemum cultivars, namely, Peach ND (PN), Peach Red (PR), and Vivid Scarlet (VD) containing RsMYBI

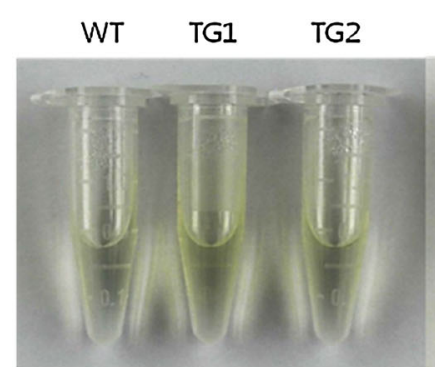

Peach ND
WT TG1 TG2

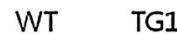

TG1

TG2

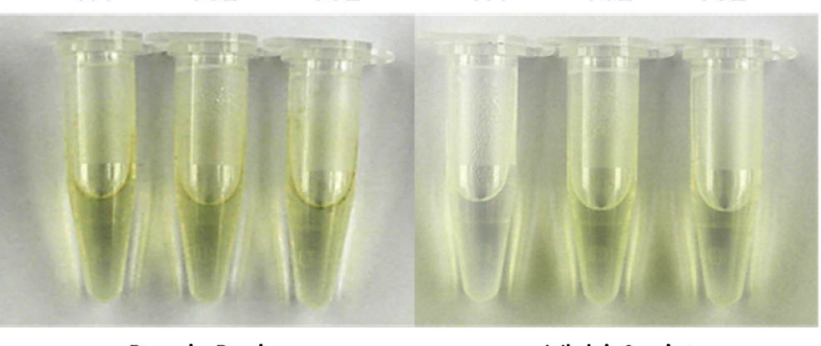

Peach Red
Fig. 5 Spectrophotometeric analysis of anthocyanin content between the non-transgenic (wild type) and transgenic lines of the chrysanthemum cultivars, namely, Peach ND (PN), Peach Red (PR), and Vivid Scarlet (VD) containing RsMYB1. Bar stands for standard error. Means marked with same letter within the same cultivar are not significantly different

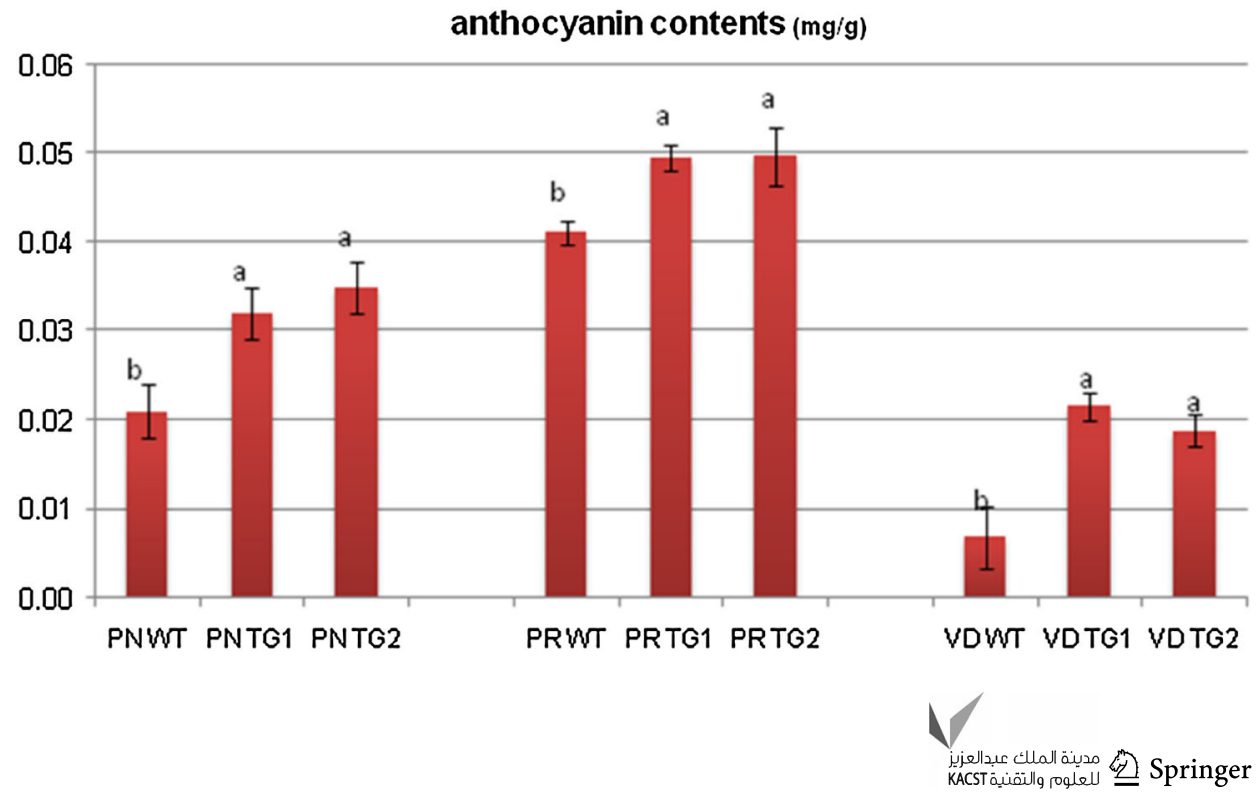


pathway. Therefore, we assumed that it is possible to use the radish $R S M Y B 1$ transcription factor, which belongs to the R2R3-MYB transcription factor family and was found to be highly expressed in the skin and flesh of three radish cultivars and responsible for anthocyanin accumulation (Park et al. 2011), to enhance anthocyanin biosynthesis in the chrysanthemum cultivars 'Peach ND', 'Peach Red', and 'Vivid Scarlet', which showed anthocyanin degradation under elevated temperatures.

Here, we produced two individual transgenic lines from each cultivar. However, not all shoots that showed positive results for the introduced RsMYBI exhibited anthocyaninenhancing phenotypes. Butaye et al. (2005) claimed that this type of variation among individual transgenic plants/ genotypes is often observed in plant transformation experiments and can be explained by variation in the expression of the introduced RsMYBI. Analysis of RsMYBI expression in the transgenic lines was shown to be stable using RT-PCR; this was not consistent with the claim of Butaye et al. (2005).

In addition, many researchers have documented that anthocyanin accumulation in chrysanthemum correlated with the expression pattern of biosynthetic genes (Chen et al. 2012; He et al. 2013; Sung et al. 2013). Since the main anthocyanin biosynthesis pathway in chrysanthemum is the cyanidin-based pathway (He et al. 2013), CHS, CHI, $F 3 H, D F R$, and ANS are considered as five key biosynthetic genes responsible for anthocyanin accumulation in chrysanthemum. Our results show that the expression of $R s M Y B 1$ in chrysanthemum could enhance the expression level of key biosynthetic genes (F3H, DFR, and ANS), although anthocyanin accumulation is not visible in the cultivars. However, analysis of anthocyanin content using a spectrophotometer revealed that anthocyanin contents in transgenic lines of the cultivars were significantly higher than those in the controls. Thus, anthocyanin accumulation in the cultivars was correlated with the expression pattern of biosynthetic genes as reported by the researchers (Chen et al. 2012; He et al. 2013; Sung et al. 2013), but anthocyanin content produced by RsMYBI seemed to be genotype-dependent because enhancement of anthocyanin contents in cultivars 'Peach ND' and 'Vivid Scarlet' seemed to be higher than that in cultivar 'Peach Red' (Fig. 5). Quattrocchio et al. (1999) claimed that although MYB transcription factors could enhance anthocyanin production, different pigmentation control activities were observed in different species of Antirrhinum and Petunia. Moreover, different pigmentation effects of MYB transcription factors on berry skin color in grape (Kobayashi et al. 2004, 2005) and tuber color in potato (De Jong et al. 2004) have also been reported. There seems to be some variation in the ability of transcription factors to control anthocyanin production in different genotypes.

Color pigmentation in petunia due to RsMYBI was visually shown in our preliminary experiment (data not shown). In addition, enhancement of anthocyanin contents in the cultivars by RSMYBI was observed in this study. However, the reason why increased anthocyanin content was not visually observed in the cultivars is unclear. One possible explanation is that anthocyanin contents induced by $R S M Y B 1$ was not dramatic in these cultivars. Another possible explanation is that the expression levels of $F 3 H$, $D F R$, and ANS were not high enough to enhance high anthocyanin content. Otherwise, it might be that expression of MYB transcription factor alone is not able to enhance strong anthocyanin accumulation in chrysanthemum, because the expression of MYB transcription factor alone failed to express anthocyanin in Arabidopsis and tobacco (Lloyd et al. 1992), and grape (Hichri et al. 2011). Alternatively, it also might be due to lack of basic helix-loophelix (bHLH) expression in the chrysanthemums because, in several other cases, co-expression of MYB transcription factor and a bHLH partner are required to strongly express anthocyanin (Butelli et al. 2008; Lloyd et al. 1992; Quattrocchio et al. 1998). Therefore, we will conduct further experiments to reveal the reason why increased anthocyanin was not visually observed in the transgenic chrysanthemums expressing RsMYBI.

\section{Conclusions}

We produced transgenic chrysanthemums that expressed RsMYB1 and demonstrated the effects of its ectopic expression on the expression levels of anthocyanin biosynthetic genes. This study revealed that RsMYBI could enhance the expression of the biosynthetic genes $(F 3 H$, $D F R$, and $A N S$ ) in transgenic lines of the cultivars Peach ND, Peach Red, and Vivid Scarlet and increase anthocyanin contents in the cultivars. The reason for the lack of visual enhancement in anthocyanin contents is still unknown. Accordingly, further studies on promoter functions and environmental conditions that affect the anthocyanin production pathway are necessary to understand the regulatory mechanism underlying anthocyanin biosynthesis. Overall, our study provides important information regarding the role of $R S M Y B 1$ in the regulation of key anthocyanin biosynthetic genes in chrysanthemums.

Acknowledgments This study was supported by the Bio-industry Technology Development Program, Ministry for Food, Agriculture, Forestry and Fisheries, Republic of Korea, and Kyungpook National University Research Fund, 2012. 


\section{Compliance with ethical standards}

Conflict of interest The authors declare that there is no conflict of interest.

Open Access This article is distributed under the terms of the Creative Commons Attribution 4.0 International License (http:// creativecommons.org/licenses/by/4.0/), which permits unrestricted use, distribution, and reproduction in any medium, provided you give appropriate credit to the original author(s) and the source, provide a link to the Creative Commons license, and indicate if changes were made.

\section{References}

Butaye K, Cammue B, Delauré S, De Bolle M (2005) Approaches to minimize variation of transgenic expression in plants. Mol Breed 16:79-91

Butelli E, Titta L, Giorgio M, Mock HP, Matros A, Peterek S, Schijlen EGWM, Hall RD, Bovy AG, Luo J, Martin C (2008) Enrichment of tomato fruit with health-promoting anthocyanins by expression of select transcription factors. Nat Biotechnol 26:1301-1308

Chen SM, Li CH, Zhu XR, Deng YM, Sun W, Wang LS, Chen FD, Zhang Z (2012) The identification of flavonoids and the expression of genes of anthocyanin biosynthesis in the chrysanthemum flowers. Biol Plant 56:458-464

De Jong WS, Eannetta NT, De Jong DM, Bodis M (2004) Candidate gene analysis of anthocyanin pigmentation loci in the Solanaceae. Theor Appl Genet 108:423-432

Dela G, Or E, Ovadia R, Nissim-Levi A, Weiss D, Oren-Shamir M (2003) Changes in anthocyanin concentration and composition in 'Jaguar' rose flowers due to transient high-temperature conditions. Plant Sci 164:333-340

Espley RV, Hellens RP, Putterill J, Stevenson DE, Kutty-Amma S, Allan AC (2007) Red colouration in apple fruit is due to the activity of the MYB transcription factor, MdMYB10. Plant $\mathrm{J}$ 49:414-427

Eun JH, Hak KS, Seong YC, Oh GK, Young RL (2008) Thermosusceptible developmental stage in anthocyanin accumulation and color response to high temperature in red chrysanthemum cultivars. Kor J Hort Sci Technol 26:357-361

He H, Ke H, Keting H, Qiaoyan X, Silan D (2013) Flower colour modification of chrysanthemum by suppression of $F 3^{\prime} H$ and overexpression of the exogenous Senecio cruentus $F 3^{\prime} 5^{\prime} H$ gene. PLoS One 8:e74395

Hichri I, Barrieu F, Bogs J, Kappel C, Delrot S, Lauvergeat V (2011) Recent advances in the transcriptional regulation of the flavonoid biosynthetic pathway. J Exp Bot 62:2465-2483

Jackson D, Culianez-Macia F, Prescott AG, Roberts K, Martin C (1991) Expression patterns of myb genes from Antirrhinum flowers. Plant Cell 3:115-125

Kobayashi S, Goto-Yamamoto N, Hirochika H (2004) Retrotransposon-induced mutations in grape skin color. Science 304:982

Kobayashi S, Goto-Yamamoto N, Hirochika H (2005) Association of VvmybAl gene expression with anthocyanin production in grape (Vitis vinifera) skin-color mutants. J Jpn Soc Hort Sci 74:196-203

Lin-Wang K, Bolitho K, Grafton K, Kortstee A, Karunairetnam S, McGhie TK, Espley RV, Hellens RP, Allan AC (2010) An R2R3 MYB transcription factor associated with regulation of the anthocyanin biosynthetic pathway in Rosaceae. Plant Biol 10:50

Lin-Wang K, Micheletti D, Palmer J, Volz R, Lozano L, Espley R, Hellens RP, Chagne D, Rowan DD, Troggio M, Iglesias I, Allan
AC (2011) High temperature reduces apple fruit colour via modulation of the anthocyanin regulatory complex. Plant Cell Environ 34:1176-1190

Lloyd AM, Walbot V, Davis RW (1992) Arabidopsis and Nicotiana anthocyanin production activated by maize regulators $\mathrm{R}$ and $\mathrm{C} 1$. Science 258:1773-1775

Lo Piero AR, Puglisi I, Rapisarda P, Petrone G (2005) Anthocyanins accumulation and related gene expression in red orange fruit induced by low temperature storage. J Agric Food Chem 53:9083-9088

Mano H, Ogasawara F, Sato K, Higo H, Minobe Y (2007) Isolation of a regulatory gene of anthocyanin biosynthesis in tuberous roots of purple-fleshed sweet potato. Plant Physiol 143:1252-1268

Morita Y, Saitoh M, Hoshino A, Nitasaka E, Iida S (2006) Isolation of cDNAs for R2R3-MYB, bHLH and WDR transcriptional regulators and identification of $\mathrm{c}$ and ca mutations conferring white flowers in the Japanese morning glory. Plant Cell Physiol 47:457-470

Naing AH, Park KI, Lim SH, Kim CK (2014) Appropriate choice of antibiotics for plant regeneration and optimization of selective agents to be used in genetic transformation of chrysanthemum. Plant Omics 7:237-243

Naing AH, Park KI, Chung MY, Lim KB, Kim CK (2015a) Optimization of factors affecting efficient shoot regeneration in chrysanthemum cv. Shinma. Braz J Bot. doi:10.1007/s40415015-0143-0

Naing AH, Lim KB, Kim CK (2015b) The usage of snapdragon Delila $(\mathrm{Del})$ gene as a visible selection marker for the antibioticfree transformation system. J Plant Biol 58:110-116

Naing AH, Ai TN, Jeon SM, Park KI, Lim SH, Lim KB, Kim CK (2016) Novel antibiotics enhance regeneration and genetic transformation with RsMYB1 gene of recalcitrant chrysanthemum cv. Shinma. Plant Biosystems. doi:10.1080/11263504. 2015.1103800

Nakatsuka T, Haruta KS, Pitaksutheepong C, Abe Y, Kakizaki Y, Yamamoto K, Shimada N, Yamamura S, Nishihara M (2008) Identification and characterization of R2R3-MYB and bHLH transcription factors regulating anthocyanin biosynthesis in gentian flowers. Plant Cell Physiol 49:1818-1829

Nishihara M, Nakatsuka T (2011) Genetic engineering of flavonoid pigments to modify flower color in floricultural plants. Biotechnol Lett 33:433-441

Park NI, Xu H, Li X, Jang IH, Park S, Ahn GH, Lim YP, Kim SJ, Park SU (2011) Anthocyanin accumulation and expression of anthocyanin biosynthetic genes in radish (Raphanus sativus). J Agric Food Chem 59:6034-6039

Pattanaik S, Kong Q, Zaitlin D, Werkman JR, Xie CH, Patra B, Yuan $\mathrm{L}$ (2010) Isolation and functional characterization of a floral tissue-specific R2R3 MYB regulator from tobacco. Planta 231:1061-1076

Quattrocchio F, Wing JF, van der Woude K, NM Mol J, Koes R (1998) Analysis of bHLH and MYB domain proteins: speciesspecific regulatory differences are caused by divergent evolution of target anthocyanin genes. Plant J 13:475-488

Quattrocchio F, Wing J, van der Woude K, Souer E, de Vetten N, Mol J, Koes R (1999) Molecular analysis of the anthocyanin2 gene of petunia and its role in the evolution of flower color. Plant Cell 11:1433-1444

Quattrocchio F, Verweij W, Kroon A, Spelt C, Mol J, Koes R (2006) $\mathrm{PH} 4$ of petunia is an R2R3 MYB protein that activates vacuolar acidification through interactions with Basic-Helix-Loop-Helix transcription factors of the anthocyanin pathway. Plant Cell 18:1274-1291

Shvarts M, Borochov A, Weiss D (1997) Low temperature enhances petunia flower pigmentation and induces chalcone synthase gene expression. Physiol Plant 99:67-72 
Sung SY, Kim SH, Velusamy V, Lee YM, Ha BK, Kim JB, Kang SY, Kim HG, Kim DS (2013) Comparative gene expression analysis in a highly anthocyanin pigmented mutant of colorless chrysanthemum. Mol Biol Rep 40:5177-5189

Ubi BE, Honda C, Bessho H, Kondo S, Wada M, Kobayashi S, Moriguchi T (2006) Expression analysis of anthocyanin biosynthetic genes in apple skin: effect of UV-B and temperature. Plant Sci 170:571-578
Yamagishi M, Shimoyamada Y, Nakatsuka T, Masuda K (2010) Two $R 2 R 3-M Y B$ genes, homologs of petunia AN2, regulate anthocyanin biosyntheses in flower Tepals, tepal spots and leaves of asiatic hybrid lily. Plant Cell Physiol 51:463-474

Yamane T, Jeong ST, Goto-Yamamoto N, Koshita Y, Kobayashi S (2006) Effects of temperature on anthocyanin biosynthesis in grape berry skins. Am J Enol Vitic 57:54-59 